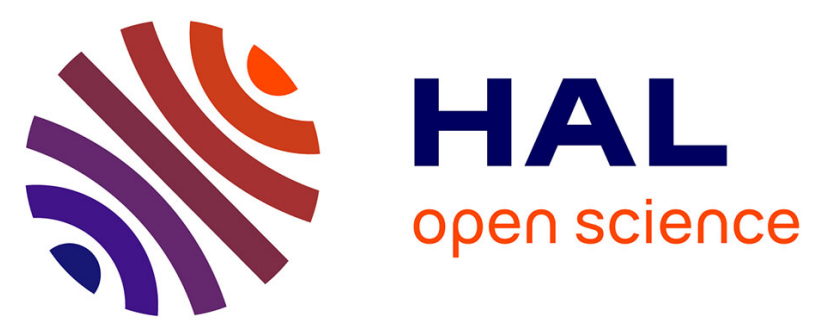

\title{
Deep reflection seismic imaging of the internal zone of the South Armorican Hercynian belt (western France) (ARMOR 2/Géofrance 3D Program) Imagerie sismique de la zone interne de la chaîne hercynienne sud-armoricaine (projet Armor 2/programme Géofrance $3 \mathrm{D})$
}

Adnand Bitri, Denis Gapais, Florence Cagnard, Charles Gumiaux, Jean Chantraine, Guillaume Martelet, Catherine Truffert, Jean-Pierre Brun

\section{To cite this version:}

Adnand Bitri, Denis Gapais, Florence Cagnard, Charles Gumiaux, Jean Chantraine, et al.. Deep reflection seismic imaging of the internal zone of the South Armorican Hercynian belt (western France) (ARMOR 2/Géofrance 3D Program) Imagerie sismique de la zone interne de la chaîne hercynienne sud-armoricaine (projet Armor 2/programme Géofrance 3D). Comptes Rendus Géoscience, 2010, 342 (6), pp.448-452. 10.1016/j.crte.2010.03.006 . insu-00495080

\section{HAL Id: insu-00495080 \\ https://hal-insu.archives-ouvertes.fr/insu-00495080}

Submitted on 10 Feb 2011

HAL is a multi-disciplinary open access archive for the deposit and dissemination of scientific research documents, whether they are published or not. The documents may come from teaching and research institutions in France or abroad, or from public or private research centers.
L'archive ouverte pluridisciplinaire HAL, est destinée au dépôt et à la diffusion de documents scientifiques de niveau recherche, publiés ou non, émanant des établissements d'enseignement et de recherche français ou étrangers, des laboratoires publics ou privés. 


\title{
Deep reflection seismic imaging of the internal zone of the South Armorican Hercynian belt (western France) (ARMOR 2/Géofrance 3D Program)
}

\section{Imagerie sismique de la zone interne de la chaîne hercynienne sud- armoricaine (projet Armor 2/programme Géofrance 3D)}

\author{
Adnand Bitri ${ }^{a}$, Jean-Pierre Brun ${ }^{b}$, Denis Gapais ${ }^{\underline{b}}$, Florence Cagnard ${ }^{\mathrm{a}}$, Charles

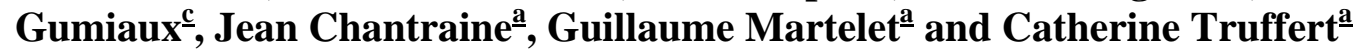 \\ a BRGM, GEO, 3, avenue Claude-Guillemin, BP 6009, Orléans cedex 2, France \\ ${ }^{\mathrm{b}}$ UMR 6118 CNRS, géosciences Rennes, université de Rennes-1, campus de Beaulieu, 35042 \\ Rennes cedex, France \\ c ISTO, université d’Orléans, 45067 Orléans cedex 2, France
}

\begin{abstract}
We present results and interpretation of a $72 \mathrm{~km}$ long deep seismic reflection profile acquired across the internal zone of the Hercynian belt of South Brittany. The profile is of excellent quality, most of the crust being highly reflective. The "ARMOR 2 South" profile, is correlated with the "ARMOR 2 North” profile that was published in 2003. Correlation of the main subsurface reflections with surface geological and structural data provides important information about the crustal structure that resulted from thickening during Late Devonian and regional-scale extension during Late Carboniferous. In particular, seismics image shows a very high reflectivity zone, lying flat over more than $40 \mathrm{~km}$ at about 10-12 km depth. This zone is interpreted as a major zone of ductile crustal thinning.
\end{abstract}

\section{Résumé}

Nous présentons les résultats et l'interprétation d'un profil de sismique réflexion en écoute longue, de 72 km de long à travers les zones internes de la chaîne hercynienne sudarmoricaine. Le profil est d'excellente qualité, avec une forte réflectivité à travers toute la croûte. Le profil, «ARMOR 2 Sud », est corrélé avec le profil «ARMOR 2 Nord » publié en 2003. Les corrélations des réflexions les plus superficielles avec les données géologiques et structurales de surface fournissent d'importantes informations sur la structure crustale qui résulte d'un épaississement débutant au Dévonien supérieur et d'une extension régionale au Carbonifère supérieur. En particulier, la sismique met en évidence une zone sub-horizontale à très forte réflectivité, de plus de 40 km de long à environ 10-12 km de profondeur. Cette zone est interprétée comme une zone d'amincissement crustal majeur.

Keywords: Hercynian collision; Crustal extension; Deep reflection seismics; South Armorican domain; France

Mots clés: Collision hercynienne; Extension crustale; Sismique réflexion; Domaine SudArmoricain; France 


\section{Introduction}

The internal zones of the Hercynian belt of Brittany (western France) are marked by crustal stacking recorded from Late Devonian times (Bosse et al., 2002) and followed by regional extension during Late Carboniferous times ([Burg et al., 1994], [Cagnard et al., 2004] and [Gapais et al., 1993]). The extension is limited to the north by the southern branch of the South Armorican Shear Zone (SASZ), a major dextral wrench zone (Jégouzo, 1980) (Fig. 1a).

A first seismic reflection profile, about $70 \mathrm{~km}$ long, striking about north-south across the SASZ, was acquired in 2000 and published in 2003 ("ARMOR 2 North" profile, [Bitri et al., 2003]). In 2002, the profile was extended to the south by a new line ("ARMOR 2 South" profile). This article presents results and structural interpretation of this second profile (Fig. 1a).

\section{Geological and structural setting}

Three main groups of units are exposed in the South Armorican domain (Fig. 1) that, from top to base, consist in:

- blueschists (Bois de Céné and Ile de Groix) (

Bosse et al., 2002

);

• metavolcanic and metasedimentary rocks, so-called "Porphyroid nappe” (

[Colchen and Poncet, 1987] and [Vauchez et al., 1987]), that also record a HP-LT metamorphic history (Le Hébel et al., 2002);

- and a metasedimentary pile affected by Barrovian metamorphism ([Ters, 1972], [Goujou, 1992] and [Triboulet and Audren, 1988]) known as the Sables d'Olonne metamorphic series (Cagnard et al., 2004).

The two upper units recorded burial to HP-LT metamorphic conditions and later exhumation from 370 to $350 \mathrm{Ma}$ ([Bosse et al., 2002] and [Le Hébel et al., 2002]). At Brétignoles-sur-Mer (Fig. 1), the porphyroid nappe is thrust on top of Tournaisian low-grade metasediments of the Sables d'Olonne series ([Colchen and Poncet, 1987] and [Iglesias and Brun, 1976]). In the Sables d'Olonne series, Barrovian metamorphism increases in grade downward up to the development of migmatites with peak conditions around $750{ }^{\circ} \mathrm{C}$ and 800-1000 MPa ([Goujou, 1992] and [Jones and Brown, 1990]). Geochronological data indicate a rapid cooling of migmatites around 310-300 Ma ([Brown and Dallmeyer, 1996], [Gapais et al., 1993] and [Goujou, 1992]) related to exhumation during regional-scale extension ([Cagnard et al., 2004] and [Gapais et al., 1993]) that brought into contact HT metamorphic domes with the actual supracrustal domains, made of previously exhumed HP-LT metamorphic units (Fig. 1b).

\section{Seismic profile}




\subsection{Acquisition and data processing}

The approximately north-south striking profile is about $72 \mathrm{~km}$ long, extending from Le Pont Béranger, south of Nantes, to La Brochetière, east of l'Ile d'Olonne (Fig. 1a). Data were acquired and processed by the Compagnie générale de géophysique in September-October 2002.

The source consisted of five vibrators AMG MERTZ 22 operating simultaneously, spaced at $12.5 \mathrm{~m}$, with a $16 \mathrm{sec}$ sweep. One vibrated point comprised the sum of nine linear sweeps with a $10-40 \mathrm{~Hz}$ frequency. Reflected waves were recorded by 244 traces with $50 \mathrm{~m}$ spacing and 24 geophones per trace - i.e. total length of 12,150 m. Shots were operated from the middle of the geophone line. Shot points with $200 \mathrm{~m}$ spacing along the profile led a theoretical coverage of 30 . The seismic signal was recorded on 14 sec with a sampling step of 4 ms.

Data processing comprised in particular statistical corrections, velocity analyses, dip corrections, summation, filtering and time migration using wave equations.

\subsection{Profile description}

Fig. 2a shows the "ARMOR 2 South" profile (from 0 to about 2700 CDP) and its northward prolongation (from about 2700 to $3200 \mathrm{CDP}$ ) along the previously acquired "ARMOR 2 North” profile (Bitri et al., 2003). The section is of high quality and reveals a strong reflectivity throughout almost the entire crust (Fig. 2a).

The lower crust is strongly reflective all along the profile and appears to thicken from about 2-3 km to the north to about 5-7 km to the south. The Moho depth is rather constant, around $31-32 \mathrm{~km}$.

The upper crust shows several high to very high reflectivity zones. The most striking is a subhorizontal band of very high reflectivity, located around $10 \mathrm{~km}$ depth, with a length of about $40 \mathrm{~km}$ and a 1-2 km thickness. To the north, this band merges in a large antiformal structure imaged on both ARMOR 2 North (Bitri et al., 2003) and South profiles. Below this zone, most reflections are shallowly dipping and are organised in several more or less continuous bands.

\section{Interpretation, discussion}

\subsection{Correlations with surface geology}

Some groups of reflections may be correlated with surface data. In the southern part, Northdipping foliations observed in the Sables d'Olonne metamorphic pile (average dip of about $30^{\circ}$ ) ([Cagnard et al., 2004], [Goujou, 1992] and [Iglesias and Brun, 1976]) can be extended downward, with a decrease in dip down to a sub-horizontal attitude between 5 and $15 \mathrm{~km}$. Above, the base of the "Porphyroid nappe" can also be extended downward parallel to northdipping reflections. This contact is connected to a zone of sub-horizontal reflections at about $5 \mathrm{~km}$ depth (zone 1, Fig. 2b). 
To the north of the profile, an antiformal structure is located below the orthogneissic unit of Mervent-Ste Pazanne, interpreted as a thrust slice rooted in the southern border of the Essarts eclogitic unit, along a southernmost branch of the SASZ (Godard, 2001) (Fig. 1a). This particular zone remains however very poorly constrained by field and seismic data (zone 2, Fig. 2b). We infer that the orthogneissic thrust unit results from late transpression along the southernmost branch of the SASZ. The antiform located below the orthogneissic unit is attributed to the St Nazaire migmatitic dome that crops out just north of the profile termination and is also imaged on the "ARMOR 2 North" profile ([Fig. 1] and [Fig. 2]).

In the central part of the profile, where HP-LT metamorphic units crop out, correlations are more difficult because of rather weak reflectivity. The interpretation we propose takes into account:

- the surface geology;

- the fact that all major contacts observed are of thrust type;

- and the fact that normal brittle faults coeval with the Late Carboniferous extension may disturb the geometry of preexisting structures.

Consequently, we interpret sharp interruptions of high reflectivity bands (e.g. zone 3, Fig. 2b) as a consequence of brittle normal faulting (Fig. 2c).

\subsection{Significance of the high reflectivity zone at $10-12 \mathrm{~km}$ depth}

The sub-horizontal high reflectivity band located at 10-12 km depth has two major characteristics: it can be followed on long distance and it does not appear disturbed by overlying or underlying reflections (Fig. 2b). These features show that this seismic structure cannot be attributed to a particular lithology and may actually be interpreted as a relatively late tectonic structure.

To the north, the band appears to merge with the St Nazaire migmatitic dome ([Fig. 1] and [Fig. 2]) whose overall geometry is comparable to the Golfe du Morbihan extensional core complex, located more to the west and exhumed during Late Carboniferous (Gapais et al., 1993). To the south, the St Nazaire dome is bounded by a normal shear zone overlain by HPLT metamorphic units ([Fig. 1] and [Fig. 2]).

To the south, the high reflectivity band is connected with a domain of north-dipping reflections correlated with the Sables d'Olonne metamorphic dome, cored by migmatites and orthogneisses ([Fig. 1] and [Fig. 2]) (Cagnard et al., 2004). At regional-scale, synmetamorphic stretching lineations strike east-west to WNW-ESE and are associated with topto-the-west relative motion ([Brun and Burg, 1982], [Cagnard et al., 2004], [Goujou, 1992] and [Vauchez et al., 1987]), as a result of intense pervasive thinning of the metamorphic pile (of the order of 80\%) (Cagnard et al., 2004). The age of extension is well documented, around 310-300 Ma (Goujou, 1992), coeval with extensional structures developed farther northwest (Gapais et al., 1993).

Other metamorphic and granitic domes (La Roche-sur-Yon, Aubigny, Fig. 1a), which also exhumed during Late Carboniferous (Goujou, 1992), occur in the southern part of the region. These domes trend about NW-SE and are mantled by lower-grade metamorphic units. The 
western domes boundary strikes about north-south and dips to the west and corresponds to a normal shear zone (Fig. 1a) (Cagnard et al., 2004). We interpret the high reflectivity zone at 10-12 km depth as the westward prolongation of this extensional shear zone. The wavy reflections below the zone likely correspond to the westward continuation of the Aubigny and La Roche-sur-Yon domes (Fig. 2c). In summary, this seismic line portrays at crustal-scale the structure resulting from major extension and thinning that affected the South Armorican Domain during the Late Carboniferous.

\section{Conclusions}

The “ARMOR 2 South” profile provided a seismic image of excellent quality, with a high reflectivity nearly throughout the entire crust, well correlated with the previously acquired “ARMOR 2 North” profile. Surface geology constrains the interpretation of the upper part of the profile in terms of thrust tectonics reworked by normal faults and low-angle shear zones of Late Carboniferous age.

A remarkable structure imaged on the profile is a very high reflectivity zone located at about 10-12 km depth. This flat-lying zone extends for more than $40 \mathrm{~km}$ and merges, to the north, in the St Nazaire migmatitic dome and, to the south, in the zone of intense crustal thinning that affects the Sables d'Olonne metamorphic series. We interpret this zone as a major zone of extensional shearing and crustal thinning developed during Late Carboniferous extension. Below this extensional shear zone, the wavy reflection pattern of the lower crust can be correlated with the St Nazaire, La Roche-sur-Yon and Aubigny domes. The Late

Carboniferous extensional structures are superposed onto a stack of HP-LT metamorphic units, thrust and then exhumed in Early Carboniferous.

\section{Acknowledgments}

The authors thank Patrick Ledru and Philippe Matte (Director and President of the scientific comity of the Géofrance 3D Program (BRGM et CNRS-INSU), respectively) for their support in the development of the ARMOR 2 Project. We thank two anonymous reviewers for constructive remarks and suggestions of improvement.

\section{References}

Bitri et al., 2003 A. Bitri, M. Ballèvre, J.P. Brun, J. Chantraine, D. Gapais, P. Guennoc, C. Gumiaux and C. Truffert, Imagerie sismique de la zone de collision hercynienne dans le SudEst du Massif armoricain (projet Armor 2/programme Géofrance 3D), C. R. Geoscience 335 (2003), pp. 969-979.

Bosse et al., 2002 V. Bosse, M. Ballèvre and O. Vidal, Ductile thrusting recorded by the garnet from the blueschist-facies metapelites of the Ile de Groix, Armorican Massif, France, $J$. Petrol. 43 (3) (2002), pp. 485-510.

Brown and Dallmeyer, 1996 M. Brown and R.D. Dallmeyer, Rapid Variscan exhumation and the role of magma in core complex formation: southern Brittany metamorphic belt, France, $J$. Metam. Geol. 14 (1996), pp. 361-379. 
Brun and Burg, 1982 J.P. Brun and J.P. Burg, Combined thrusting and wrenching in the Ibero-Armorican Arc: a corner effect during continental collision, Earth Planet. Sci. Lett. 61 (1982), pp. 319-332.

Burg et al., 1994 J.P. Burg, J. Van den Driessche and J.P. Brun, Syn- to post-thickening extension in the Variscan belt of western Europe: modes and structural consequences, Geol. Fr. 3 (1994), pp. 33-51.

Cagnard et al., 2004 F. Cagnard, D. Gapais, J.P. Brun, C. Gumiaux and J. Van Den Driessche, Late pervasive crustal extension in the south Armorican Hercynian belt (Vendée, France), $J$. Struct. Geol. 26 (2004), pp. 435-449.

Colchen and Poncet, 1987 M. Colchen and D. Poncet, Sur l'âge post-Tournaisien de la tectonique hercynienne syn-schisteuse à Brétignolles-sur-Mer, Vendée littorale, C. R. Acad. Sci. Paris, Ser. II 305 (1987), pp. 1255-1258.

Gapais et al., 1993 D. Gapais, J.L. Lagarde, C. Le Corre, C. Audren, P. Jégouzo, A. Casas Sainz and J. Van den Driessche, La zone de cisaillement de Quiberon : témoin d'extension de la chaîne varisque en Bretagne méridionale au Carbonifère, C. R. Acad. Sci. Paris, Ser III 316 (1993), pp. 1123-1129.

Godard, 2001 G. Godard, Les Essarts eclogite-bearing complex (Vendée), Geol. France 1-2 (2001), pp. 19-51.

Goujou, 1992 J.C. Goujou, Analyse pétro-structurale dans un avant-pays métamorphique : influence du plutonisme tardi-orogénique varisque sur l'encaissant épi à mésozonal de Vendée, Doc. Bur. Rech. Geol. Minière (1992), p. 216.

Iglesias and Brun, 1976 M. Iglesias and J.P. Brun, Signification des variations et anomalies de la déformation dans un segment de la chaîne hercynienne (les séries cristallophylliennes de la Vendée littorale, Massif armoricain, Bull. Soc. Geol. France 7 (1976), pp. 1443-1452.

Jégouzo, 1980 P. Jégouzo, The South Armorican Shear Zone, J. Struct. Geol. 2 (1-2) (1980), pp. 39-47.

Jones and Brown, 1990 K.A. Jones and M. Brown, High-temperature « clockwise » P-T paths and melting in the development of regional migmatites: an example from southern Brittany, France, J. Metam. Geol. 8 (1990), pp. 551-578.

Le Hébel et al., 2002 F. Le Hébel, O. Vidal, J.R. Kienast and D. Gapais, Les « Porphyroïdes » de Bretagne méridionale : une unité de HP-BT dans la chaîne hercynienne, $C$. R. Geoscience 334 (2002), pp. 205-211.

Ters, 1972 M. Ters, Sur l'extension du Paléozoïque en Vendée littorale. Stratigraphie et structure, C. R. Somm. Soc. Geol. France (1972), pp. 1146-1148.

Triboulet and Audren, 1988 C. Triboulet and C. Audren, Controls of P-T deformation path from amphibole zonation during progressive metamorphism of basic rocks (Estuary of the river Vilaine, South Brittany, France), J. Metam. Geol. 6 (1988), pp. 117-133 
Vauchez et al., 1987 A. Vauchez, D. Maillet and J. Sougy, Strain and deformation mechanisms in the Variscan nappes of Vendée, South Brittany, France, J. Struct. Geol. 9 (1987), pp. 31-40. 


\section{Figures}

(a) $\square$ Eclogitic Units (Essarts and Champtoceaux)
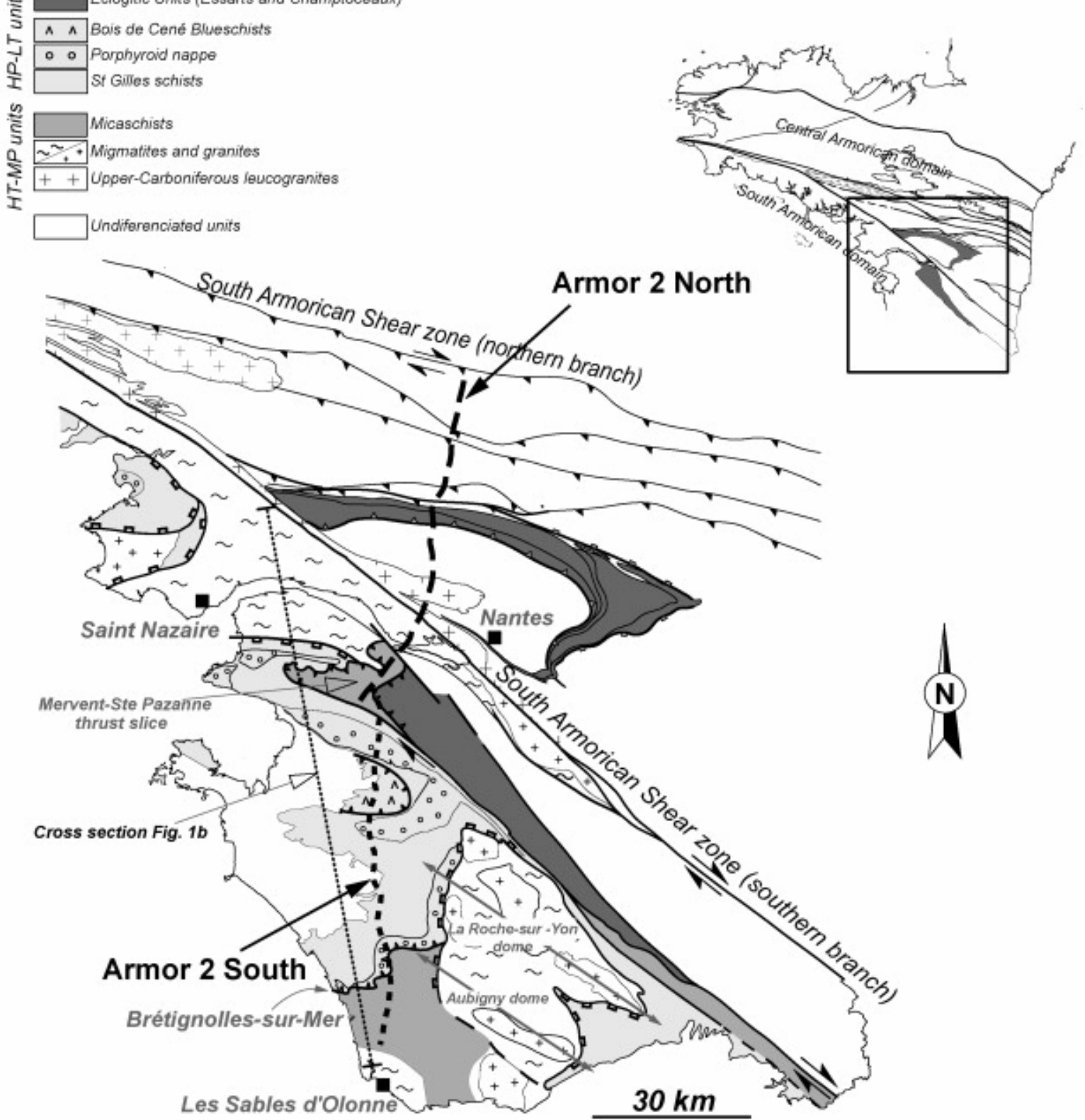

(b)

$N-N W$

S-SE

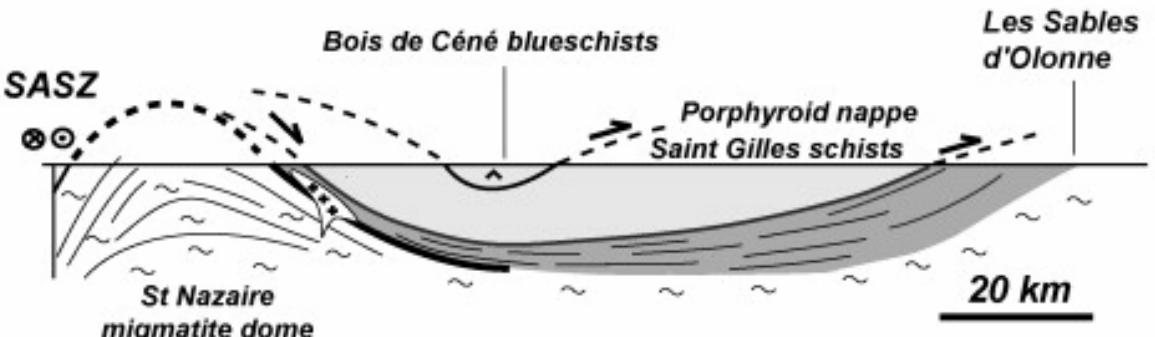

Fig. 1. a: location of the ARMOR 2 North and ARMOR 2 South seismic profiles on a simplified geological map; b: sketch cross-section (located on (a), modified after [Cagnard et al., 2004]). a : localisation des profils sismiques ARMOR 2 Nord et ARMOR 2 Sud sur une carte géologique simplifiée ; b : coupe géologique schématique subméridienne (localisée en (a), modifiée d'après [Cagnard et al., 2004]). 

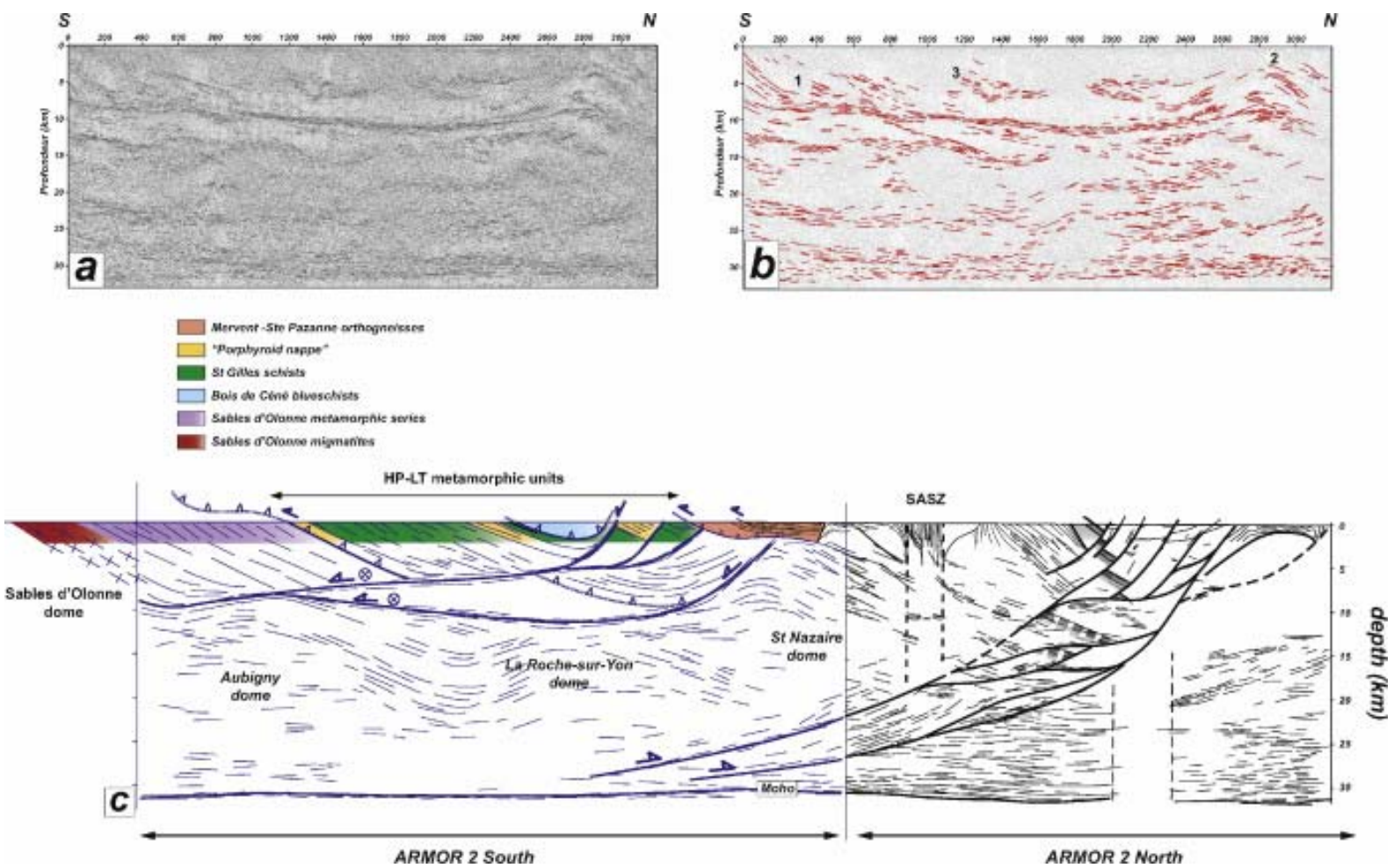

Fig. 2. a: data from the ARMOR 2 South profile; b: extraction of main reflections (zones 1, 2 and 3 are discussed in text); c: interpretation of the ARMOR 2 South profile and correlation with the ARMOR 2 North profile (Bitri et al., 2003). a : données du profil ARMOR 2 Sud ; b : extraction des principales réflexions (les zones 1, 2 et 3 sont discutées dans le texte) ; c : interprétation du profil ARMOR 2 Sud et corrélation avec le Profil ARMOR 2 Nord (Bitri et al., 2003). 